\title{
CSR and the Debate on Business and Human Rights: Bridging the Great Divide
}

\author{
Florian Wettstein \\ University of St. Gallen
}

\begin{abstract}
Human rights have not played an overwhelmingly prominent role in CSR in the past. Similarly, CSR has had relatively little influence on what is now called the "business and human rights debate." This contribution uncovers some of the reasons for the rather peculiar disconnect between these two debates and, based on it, presents some apparent synergies and complementarities between the two. A closer integration of the two debates, as it argues, would allow for the formulation of an expansive and demanding conception of corporate human rights obligations. Such a conception does not stop with corporate obligations "merely" to respect human rights, but includes an extended focus on proactive company involvement in the protection and realization of human rights. In other words, the integration of the two debates provides the space within which to formulate positive human rights obligations for corporations.
\end{abstract}

KEY WORDS: corporate social responsibility, business and human rights, multinational corporations, UN framework, human rights responsibility

\section{INTRODUCTION}

$\mathrm{U}$ NTIL VERY RECENTLY, human rights have played a rather marginal role in and for the conceptualization of CSR. In 2003, for example, Mary Robinson commented that "it remains the case that virtually all of the corporate social responsibility debates around the world make no reference to international human rights standards." (Robinson 2003: 9) Similarly, Campbell (2006: 256; see also Cragg 2000: 208) observes that for a large part, CSR codes and policies have avoided the terminology of human rights in the past. This, it seems, is about to change. Especially the publication of the two reports of UN Secretary-General's Special Representative on business and human rights (SRSG), John Ruggie, in 2008 (see United Nations 2008a, 2008b) have caught the attention of scholars concerned with CSR and have led to a noticeable increase in human rights related publications in the field. The so-called "business and human rights debate" (Chandler, 2003; Ruggie, 2007: 839) is now on the CSR radar.

One reason for this heightened interest in the business and human rights debate in the most recent past may just be the realization that the SRSG's two reports have given similarly little weight to the broader discussions on CSR. Especially the deeper moral dimension of corporate human rights responsibility, as Arnold (2010) and Cragg (2012) recently pointed out, has been sidelined by and large in the two 
reports. Thus, specific critique of the reports and indeed of the whole debate on business and human rights from the standpoint of morality certainly is warranted.

From whatever angle we look at it, there arguably is a rather peculiar disconnect between these two debates that, after all, would seem so closely related. This raises questions not only about the reasons for this divide, but, based on them, about the potential that a closer integration of the two debates would hold. Providing an answer to these two questions is the general aim of this contribution. Furthermore, it attempts to give a face to the business and human rights debate and to structure it in a way that provides useful connecting points in order to make it more readily accessible especially for scholars in the field of CSR. Finally, by proposing a more extensive conception of human rights obligations of business, one that is grounded in a moral, rather than a legal or political understanding of human rights, I hope to provide a reference point for future research in the intersection of CSR and human rights.

Starting with some brief elaborations on the moral nature of human rights, the paper will engage in two separate analyses of the business and human rights debate and of the broader debate on CSR respectively. This will reveal some apparent synergies and complementarities between those two fields; most prevalently, the often wide and proactive focus of CSR contrasts with and complements the binding character of human rights obligations. The concept of capability is a plausible meeting place of the two. Capability, as I will argue, provides a linchpin between the two debates, which allows for the formulation of an expansive and demanding conception of corporate human rights obligations. Such a conception challenges particularly the "human rights minimalism" which represents the current state of the art in the business and human rights debate. ${ }^{1}$ It does not stop with corporate obligations merely to respect human rights, as notably the SRSG's framework suggests, but includes a duty for corporations also to take pro-active and positive steps toward the protection and realization of human rights. My brief elaborations on the moral nature of human rights in the next section are meant to provide the basis on which all subsequent argumentation in this paper is built.

\section{HUMAN RIGHTS AS MORAL RIGHTS}

Human rights are commonly associated with those important documents that together constitute the International Bill of Human Rights. Similarly, one might think of institutions like the United Nations Human Rights Commission, or perhaps the European Court of Human Rights. These are all manifestations of our attempts to make human rights relevant for practice. However, in a more fundamental sense, human rights must be understood as moral concepts and thus as moral rights. They are, in Amartya Sen's (2004: 321) words "quintessentially ethical articulations, and they are not, in particular, putative legal claims."

Moral rights are pre-positive and pre-political rights; they are, in the words of Joel Feinberg (1973: 84) "held to exist prior to, or independently of, any legal or institutional rules." Hence, their validity and importance is neither dependent nor based on their codification into positive law. ${ }^{2}$ They are, again in the language of Feinberg, "especially sturdy objects to 'stand upon,' a most useful sort of moral 
furniture" (Feinberg 1980: 151). Hence, when speaking of human rights in this article, I am not, in essence, referring to the specific list of rights laid down in the Universal Declaration of Human Rights, but rather to their much broader moral foundation or ethical justification.

Human rights are moral rights of special importance; for moral rights to qualify as human rights, the claims or entitlements they address and thus the imperative deriving from them must be of particularly fundamental nature (Feinberg, 1973: 85). More precisely, they address claims that are directly connected to the basic possibility of living a human life in dignity. Against this background, we could, following Martha C. Nussbaum, define a human right as "an especially urgent and morally justified claim that a person has, simply in virtue of being a human adult, and independently of membership in a particular nation, class, sex, or ethnic, religious or sexual group"(Nussbaum 2002: 135). A human life in dignity is a life in freedom and autonomy. Thus, human rights claims refer, at their core, to the freedom and autonomy of human beings. Freedom is "what the right is a right to" (Shue 1996: 15), that is, what we enjoy, when making use of our rights. Or in other words: freedom is the substance of rights. Rights are the vehicles with which to protect our human freedoms and based on which to ensure our autonomy as human beings. Thus, human rights, as the most important and fundamental category of moral rights, protect those freedoms that are most essential for a dignified and self-determined human life (Sen 2004: 319, 321). Therefore, human rights violations always denote a form of humiliation, that is, a form of disregard of a human being's human quality (Margalit 1996: 9ff.).

It is against this background that all human rights, understood as moral rights, are by definition universal and equal rights (Werhane 1985: 12ff.; Donnelly 2003: 10). They apply to all adult human beings in the same manner and to the same extent. Furthermore, human rights are inalienable and indivisible; one is either human or not, but one cannot be more or less human. One cannot cease to be human and, accordingly, one cannot sell, trade in, or voluntarily abstain from the rights that constitute one's humanity.

\section{HUMAN RIGHTS MINIMALISM AS THE STATE OF THE ART IN "BUSINESS AND HUMAN RIGHTS"}

The intersection between business and human rights has long received relatively little academic attention. This started to change in the wake of John Ruggie's appointment as SRSG in 2005. Subsequently, in 2008 Ruggie published two much anticipated reports, which summarized his extensive effort during the previous three years (see United Nations, 2008a, 2008b). In those reports, Ruggie introduced a tripartite framework consisting of a corporate responsibility to respect human rights, the state duty to protect human rights, and the need for more effective access to remedy in cases of human rights abuse. ${ }^{3}$ It is safe to say that Ruggie's framework has since become the state of the art in the debate on business and human rights; much like one cannot write about justice without referring to John Rawls, the business and human rights debate today predominantly revolves around Ruggie's framework. 
While Ruggie's work has done much to raise the profile of the debate on business and human rights, the debate's actual starting point is commonly dated to the mid-1990s (see, e.g., Avery 2000; Chandler, 2003); companies predominantly in the extractive sector started to be called out publicly, for example, for their role in human rights violations committed by hired security forces or for their collusion with repressive governments in violently putting down demonstrations and protests. Examples include Enron in India, Unocal in Burma, ExxonMobil in Indonesia, and perhaps most prominently, Shell in Nigeria for its role in the execution of playwright and activist Ken Saro-Wiwa and the assault by the Abacha government on the fundamental rights especially of the Ogoni people in the Niger Delta. In the wake of such incidences, an increasing number of NGOs such as the Business Group of Amnesty International UK and Human Rights Watch started to scrutinize multinational companies' human rights conduct more closely and produced a steady stream of high profile reports on the subject (see, e.g., Amnesty International 1998; Human Rights Watch, 1999a, 1999b; Avery 2000; Frankental and House 2000). As a response, an increasing number of companies, among them also Shell, started to formally adopt human rights policies during that time.

What was new about this emerging debate was not per se the connection of human rights and business, but rather that its concern with human rights started to reach decisively beyond labor and employment issues, to which earlier analyses of the topic had traditionally been limited (see, e.g., Munchus 1989; Andiappan, Reavley, and Silver 1990). While the case for business responsibility in the domain of labor rights was relatively straight forward conceptually, the extension of the focus on human rights beyond this particular domain required a broader inquiry in the systematic relation between business and human rights in general. Determining and conceptualizing this relation, then, has been the principal aim at the core of what has come to be known as the "business and human rights debate."

The accumulation of human rights questions and issues that derived directly from business practices during the 1990s was, of course, not a coincidence. Rather, it was the result of the changing context of doing business in the post-Cold War global economy (see, e.g., Cassel 2001; Muchlinski 2001). The policies of liberalization, deregulation, and privatization of the Washington Consensus, which rapidly spread across the world during the late 1980s and 1990s, profoundly altered not only the size and structure of the global marketplace, but also the power relations in the global political economy (see, e.g., Mathews 1997). In this ongoing process, states are said to be losing some of their power to fully control social, economic and even political processes both in the global as well as in the domestic realm. Against this background, the effectiveness of the state as the sole protector of people's most basic rights had become questionable and the call for extending human rights responsibility to non-state actors in general and into the private sphere in particular became louder (see, e.g., Clapham 1993, 2006; Alston 2005; Andreopoulos, Arat, and Juviler 2006; Oliver and Fedtke 2007).

Conceptually, however, it is anything but crystal clear how and to what degree such an extension of human rights responsibility into the private sphere can and should take place. Particularly from the perspective of international law such ex- 
tended interpretations seemed to raise more questions than they provided answers. States were and commonly still are seen as the sole entities with international legal personality and thus as the exclusive addressees of international law. This makes them the sole bearers of direct human rights obligations at least as they pertain to international legislation. All other institutions, as a consequence, may only have indirect human rights responsibilities, insofar and to the extent as the respective governments stipulate them in their domestic legislations. However, they are not bound directly by international law (see Muchlinski, 2001: 32; 2012: 151).

Hence, much of the question about the systematic relation between business and human rights came to revolve, in one way or the other, around the issue and adequacy of state-centrism or -exclusivity in matters of international human rights policy and legislation. Concordantly, in a time in which power and authority is increasingly fragmented and shared between state and non-state actors and in which the boundaries of the private and the public sphere are blurring, the challenge at the core of the business and human rights debate came to be the one of reinterpreting and redesigning the international human rights regime in a way that would include and address also non-state actors and particularly corporations as direct duty-bearers. The debate that evolved around this question has addressed this challenge in three distinct ways.

First, it has focused on the extended reading and reinterpretation of existing international human rights legislation in order to include corporate responsibility alongside traditional state obligations (see, e.g., Ratner 2001; Jungk 2001; ICHRP 2002). For example, The Universal Declaration of Human Rights, even though principally focusing on nation-states, does not exclude other institutions as dutybearers, but explicitly states in its preamble that it applies to "every individual and every organ of society" (Weissbrodt 2005: 283; Pegg 2003: 16). Furthermore, at least in regard to the basic respect of human rights, articles 29 and 30 of the Universal Declaration as well as the corresponding articles 5 in the two Covenants state that not only states, but any person or group must resist from performing any action that might pose a threat to human rights (Frey 1997: 163).

Second, it has contemplated ways to extend domestic legislation in order to include corporations' human rights conduct abroad by exploring questions of extraterritorial (see, e.g., Skogly 2006: 23-56; Gibney and Skogly 2010; McCorquodale and Simons 2007) or universal (Muchlinski 2012: 154) jurisdiction in general or by reference to specific statutes such as the Alien Tort Claims Act in the United States (see, e.g., Forcese 2001; Kurlantzick 2004). Such cases of "foreign direct liability" hinge on the proof that a parent company was directly involved in the harm caused by one of its subsidiaries abroad — a task that, according to Peter Muchlinski (2012: 152 ) is not easy and which may lead to significant under-compensation of the victims. Nevertheless, as he asserts, "it is in this sphere that the legal development of a binding duty to respect human rights will first evolve" (Muchlinski 2012: 151).

Third, beyond the option of reinterpreting existing domestic and international legislation, it has focused on the design of a "new international normative regime" (Meyer 2003; see also Monshipouri, Welch, and Kennedy 2003), that is, on the possibility of new international codes or legislation which would directly address 
corporations' human rights conduct. This option was pursued most prominently and perhaps most contentiously by the UN Sub-Commission on the Promotion and Protection of Human Rights and its attempt to devise a set of "Norms on the Responsibility of Transnational Corporations and Other Business Enterprises with Regard to Human Rights" (UN Draft Norms). In contrast to existing codes of conduct such as the UN Global Compact, the UN Draft Norms were designed to apply to all corporations on a non-voluntary basis-although, at least in a first instance, not in a legally binding manner (see, e.g., Weissbrodt and Kruger 2003; Weissbrodt 2005). While the UN Draft Norms drew harsh criticism not only but especially from the business community (see, e.g., ICC/IOE 2004) and ultimately failed to garner broad enough support to be adopted by the UN Commission, they have done much to raise the profile of the business and human rights debate in general and can be credited with leading up to the creation of the position of the SRSG.

In sum, the main thrusts of the business and human rights debate typically have been concerned not so much with the fundamental ethical justification of corporate human rights obligations as with their implementation and potential enforceability in and through the international human rights regime. Symptomatically, Peter Muchlinski's (2001: 32) argument, for example, is aimed at the "applicability" of human rights in the private sphere, rather than with uncovering them within the normative foundations of business as such. Steven Ratner (2001: 448) even argues that any answer to the question of corporate human rights obligations that is "not depending exclusively on diverse and possibly parochial national visions of human rights and enterprise responsibility must come from international law." This does not mean that the debate over such an "extension" of human rights thinking in the private sector is entirely devoid of ethical consideration; after all, the very question of why and to what extent the international human rights regime should include also private actors is crucially dependent on ethical reflection. However, what such questions rarely address is the fundamental moral nature of human rights obligations as something that matters independently and irrespective of their implementation or enforcement.

It is against this background, that such accounts typically are based on legal or political conceptions of human rights (which can then be extended into the private sphere), rather than on moral ones, understood as the justificatory basis of human rights thinking as such (on this distinction see Arnold, 2010: 378-79). The SRSG's framework is a case in point. It explicitly refers to the International Bill of Human Rights and the ILO core conventions and thus to a combination of legal and political conceptions of human rights as the benchmarks against which to judge the human rights conduct of companies (see United Nations, 2008b: 17; Arnold, 2010: 378). As a consequence, also the imperative deriving from them is rarely grounded on a deep and genuine moral foundation (Arnold, 2010: 372). Rather, it corresponds to the legal or political conception of rights underlying it and thus is equally legal (for example, based on the reinterpretation of international law) or political (based on the agreement of corporations to initiatives like the UN Global Compact) in nature, or, alternatively, is advanced based on strategic considerations (because it allegedly is good business to uphold human rights). 
Attempts to defend corporate human rights obligations exclusively on political, legal, or strategic grounds suffer from some characteristic shortcomings and limitations. Most prevalently, they tend to rather narrowly emphasize and focus on what can (potentially) be enforced (see, e.g., Ratner 2001: 450, 530-40; ICHRP, 2002: 3, 77-120). ${ }^{4}$ As a result and according to John Ruggie's (2007: 839) own assessment, the discussion on business and human rights has been centered in large parts on wrongdoing and, accordingly, tends to adopt an overly narrow focus on corporate obligations of the negative kind, that is, on obligations of non-interference and "do no harm" (see, e.g., Jungk, 2001: 8). Symptomatically, also Ruggie's tripartite framework defines human rights obligations of corporations exclusively in negative terms as duties to respect human rights, while assigning all duties in the positive realm to the state alone.

The rigidity with which Ruggie narrows the boundaries not only of his own framework but indeed of the whole debate on business and human rights is worrisome. As Arnold's (2010) "unpacking" of the SRSG's tripartite framework shows, corporate human rights obligations cannot be convincingly defended and justified on the grounds of legal and political conceptions of human rights alone. Therefore, there is an urgent need to pay closer attention to the more inclusive moral dimension of human rights for the derivation of corporate human rights obligations. For this endeavor, and to counter what we could call Ruggie's "human rights minimalism," a more thorough look at the trends and ideas discussed in the broader field of business ethics and CSR promises to be instructive. However, following this advice one quickly realizes that, until very recently, human rights have seldom been theorized as an integral part of CSR in the past.

\section{HUMAN RIGHTS AS A BLIND SPOT IN CSR}

Corporate social responsibility is a concept that can be and has been "defined" in countless different and often conflicting ways. Therefore, trying to avoid the trap of defining something that may not have a set definition, Scherer and Palazzo (2007: 1096) refer to CSR as an "umbrella term" for all those debates that deal with the "responsibilities of business and its role in society," including subfields like business and society, business ethics, or stakeholder theory. Similarly, Jonker refers to CSR as a "sensitising concept," that is, "a term that draws attention to a complex range of issues and elements that are all related to the position and function of the business enterprise in contemporary society. As such, this umbrella term helps to identify and address what needs to be debated." (Jonker 2005: 20) From this perspective he rightly concludes "that CSR is not in itself the core issue. The term itself has no other function than to awaken sensitivity to a complex and multi-dimensional debate challenging the role of business in contemporary society." (Jonker 2005: 21) Thus, at its core, the concept of CSR deals with the very essence of what it means to do and be a business, that is, with the very purpose and ever-changing role of business within society. I will adopt this understanding of CSR also for this article. Following Scherer and Palazzo, then, I will subsume those parts of business ethics that deal directly with the moral responsibility of corporations in the reference to 
CSR. In fact, precisely those accounts of CSR which overlap with the normative focus of business ethics are of main concern to this analysis.

As mentioned earlier, human rights have played a rather peripheral role overall for the conceptualization of CSR. However, this does not mean that they have been entirely absent from the debate. Human rights related contributions to the CSR literature can be divided roughly in three overlapping waves with the first one starting in the mid-1980s, the second one starting with the sweatshop and child labor controversy in the early to mid-1990s and the third wave starting with the creation of the position of the SRSG in 2005.

The first wave of human rights related contributions to the CSR literature started to emerge in the mid-1980s (see, e.g., Post 1985; Werhane 1985; Munchus 1989; Donaldson 1989; Andiappan, Reavley, and Silver 1990). Such contributions remained rather sporadic and fragmented and, as mentioned earlier, tended to focus rather narrowly on the domain of labor rights and employment. An important exception both in regard to fragmentation and focus was the discussion on divestment from apartheid South Africa in the late 1980s (see, e.g, Williams 1986: 72-117; Di Norcia 1989; Donaldson 1989: 129-44; Sethi 1987). Granted that this discussion too centered on the question of workplace discrimination, but it transcended the confines of traditional labor issues insofar as it dealt with them in the specific context of systematic human rights abuses committed by host governments. Not surprisingly, such questions of corporate complicity (see, e.g., Clapham and Jerbi 2001; Ramasastry 2002), the role of business in zones of conflict (see, e.g., Tripathi 2005), and the relations of businesses with authoritarian governments (see, e.g., Schermerhorn 1999; Jungk 2000; Santoro 2000: 179-95; White 2004; Brenkert 2009) later became core concerns not only of the SRSG (see United Nations 2008a) but of the business and human rights debate in general. Donaldson's social contract based Ethics of International Business (see also Brenkert's (1992) response to it), which was affected, if not inspired, by the apartheid debate, deserves special mention. It may be the first comprehensive work that established human rights as the "bedrock considerations" (Donaldson 1989: 7) and thus as the "moral bottom line" for the conduct of multinational corporations.

This slow expansion of the focus beyond labor practices accelerated in the second phase of contributions (see, e.g., Smith 1994; Chandler 1998), which was heralded with the emergence of the business and human rights debate in the mid-1990s, and, for the focus of CSR perhaps more importantly, with the still ongoing sweatshop and child labor controversy that emerged around the same time. Like the earlier debate over divestment from apartheid South Africa, the one on sweatshops and child labor has transcended the traditional context of labor and employment in important ways. The context of outsourced and increasingly fragmented and dispersed global value chains raised questions not only about the universality of labor standards, but also about the extent of corporate responsibility for the conduct of suppliers and contractors (see, e.g., Santoro 2000: 18-21, 159-62; Arnold and Bowie 2003; Arnold and Hartman 2006: 684-86). Thus the question concerning the proper treatment of workers was transforming from one of predominantly internal to one of predominantly external responsibility. This is precisely why traditional labor issues increasingly 
had to be dealt with as genuine human rights problems (see, e.g., Santoro 2003a; Arnold 2003a). As a consequence, critics of sweatshops frequently evoked human rights arguments in their case against sweatshops proponents (see, e.g., Hindman and Smith 1999; Arnold 2003b; Santoro 2003b; Radin and Calkins 2006; for defenses of sweatshops see, e.g., Maitland 2004; Bhagwati 2004; Powell 2006).

This expanding focus was "institutionalized" with the introduction of the UN Global Compact in the year 2000. The UN Global Compact explicitly distinguishes between general human rights principles (principles 1 and 2) and principles specifically addressing labor practices (principles 3, 4, 5, and 6). As such, it has done much to render human rights relevant for corporations in their own right, rather than merely as add-ons to labor issues. This was reflected in a growing, although still rather small, number of contributions on the human rights implications of the UN Global Compact itself (see, e.g, Donaldson 2003; Leisinger 2003; Monshipouri, Welch, and Kennedy 2003; Williams 2004; Hsieh 2004) as well as on the conceptual relation between CSR and human rights in general (see, e.g., Santoro 2000; Cragg 2000; Frankental and House 2000; Cassel 2001; Frankental 2002) after the year 2000. The controversy surrounding the UN Draft Norms (see, e.g., Simons 2004; Wettstein and Waddock 2005; Howen 2005b) that peaked in 2003 and led up to the creation of the position of the SRSG in 2005 marks the transition into the third phase. Both the UN Draft Norms as well as the creation of the position of the SRSG represented attempts to integrate business more formally into the international human rights regime, which contributed to the widening of the gap between the debates on business and human rights and on CSR.

John Ruggie's appointment as the SRSG in 2005, finally, heralded the third phase of contributions. Especially the publication of his "Protect, Respect and Remedy Framework" three years later in 2008 significantly lifted the profile of the business and human rights debate in CSR circles. It triggered a remarkable increase not only in conceptual publications in the intersection of CSR and human rights (see, e.g., Arnold 2010; Cragg 2010; Whelan, Moon, and Orlitzky 2009; Mayer 2009; Mena et al. 2010), but also of conferences and symposia, conference contributions, ${ }^{5}$ as well as special issues on the topic by the leading journals in the field. ${ }^{6}$

Nevertheless, this continuous stream-or perhaps rather trickle-of research in the intersection of CSR and human rights since the mid-1980s cannot hide the fact that, at least up to this current third phase, human rights have not come to play a pivotal role for the general conceptualization of CSR; attempts to make human rights accessible for informing a general conceptual understanding of CSR, that is, attempts to integrate human rights at the very core of the concept such as, for example, in Donaldson's above-mentioned Ethics of International Business have generally been rare.

The "human rights minimalism" of the business and human rights debate might be part of the reason for the reluctance of the CSR community to join in the discussion. Lacking specific expertise in international human rights law, scholars generally concerned with CSR may have perceived themselves not competent to draw a great deal from human rights studies for their own writing, let alone to be able to make significant contributions to the human rights literature. ${ }^{7}$ However, at 
the heart of this divide between CSR and the debate on business and human rights, I believe, are other reasons, which deal with a perceived conceptual mismatch between conventional understandings of CSR and the nature of human rights as such. More specifically, I propose a two-pronged explanation, which derives from two different and opposing ways of how corporate social responsibility has often been perceived - as either something voluntary or as a moral obligation (on the distinction between such duty-based and voluntary conceptions of CSR in general see Dubbink and van Liedekerke 2009). For both understandings, I believe there is a plausible explanation for the relative lack of attention that has been given to human rights. In the first case, the voluntariness assumption clashes with the fundamental moral nature of human rights claims. I will call this the problem of voluntariness. In the second case, the political nature of human rights responsibilities clashes with the perceived apolitical, private nature of the corporation; thus, in this second case the divide occurs between non-political, social responsibility on the one side and political obligation on the other. I will call this the problem of non-political responsibility. In the following, let us have a closer look at both explanations.

The problem of voluntariness: Corporate social responsibility, as a concept, is often said to be dealing with those responsibilities that corporations may (or may not) adopt on a voluntary basis beyond their mere compliance with legal laws and regulations (see most strikingly European Commission 2001; Commission of the European Communities 2006; International Labour Office 2007: 115ff.). For a good part of conventional CSR thinking, this voluntariness assumption is still pervasive today; this has been noticed also by Sandra Waddock and Neil Smith: "Too much of the time when we think about . . corporate responsibility," as they confirm, "we think about it as a discretionary responsibility" (Waddock and Smith 2000: 47). I believe this perception of CSR as something "fundamentally" voluntary (Commission of the European Communities 2006: 2) is directly tied to the relative lack of attention it has given to human rights.

Three different interpretations of voluntariness strike me as relevant for my argument. First, we may define voluntariness legalistically, that is, as "non-coercion" or simply as what is not mandated by law (1). Alternatively, voluntariness may be understood more fundamentally in a moral sense, that is, as "moral discretion." This leads to the second and third interpretations. Moral discretion in a broad and sweeping sense refers to what is "morally optional," beyond any obligation, and thus supererogatory (2). Moral discretion in a more narrow sense refers to acts which are morally required in principle, but may leave some room for judgment and thus moral discretion or "latitude" (Kant) in regard to how, when, and to what extent they ought to be fulfilled. This is what Kant (1996: 31-32) called imperfect obligations (3).

(1) The notion of voluntariness or "voluntarism" (see Simons 2004; ICHRP 2002) informing today's conceptions of CSR, such as the one of the European Commission quoted above, may be a legalistic one in most cases. The reason why scholars concerned with CSR have often sidelined human rights, then, might simply be that the limited view on human rights as legal or political constructs may be dominant also in their own thinking. From that perspective, 
an understanding of CSR as voluntary responsibility beyond the law would systematically exclude human rights as a subject that warrants particular attention. Human rights responsibilities of corporations would appear to be a part of a company's legal obligations and thus to be located outside of the realm of CSR.

(2) The idea of human rights as an integral part of CSR may be similarly difficult to reconcile with a perspective of voluntariness as moral discretion. The fundamental nature of human rights obligations as "imperative and overriding" rather than "advisory and defeasible" (Campbell 2006: 263) is at odds most evidently with the more sweeping interpretation of moral discretion as supererogation and with the subsequent tendency to understand CSR as something "not universal or objective but [are] culturally relative, largely philanthropic and subjective by nature" (Robinson 2003: 9). The very notion of an obligation as "something we conceive as imposed upon our inclinations, something we must do whether we want to or not" (Feinberg 1980: 136; emphasis in original) conflicts sharply with such interpretations of voluntariness. While there was a tendency, or even a "preoccupation" (Carroll 1999: 273) ${ }^{8}$ of early CSR approaches to rely on voluntariness in a broad sense, today's debate certainly has become more diverse and more sophisticated. Nevertheless, it would be premature to argue that the field in general has fully overcome this bias. $^{9}$

(3) Even if we hold that the more sweeping view of voluntariness is not representative for the broader debate on CSR anymore, the less all-encompassing, second interpretation of moral discretion as mere latitude cannot fully eliminate the perceived tension between CSR and human rights either. The difference between perfect and imperfect obligations, at least in the widely shared Kantian conceptualization (see Kant 1996: 31-32; O’Neill 1996: 128-41; see also Mill 2001: 49), is precisely that the former derive from counterpart rights, while the latter do not. In other words, granted that imperfect obligations are indeed ethical requirements and thus, at least in principle, not a matter of voluntariness or pure discretion, but their ethical imperative is not based on rights; rather, they are commonly associated with the realm of virtue and beneficence (see, e.g., O’Neill 1996: 136-41; Frankena 1973: 46-47). Hence, conceptualizing CSR around a notion of voluntariness that resembles the characteristics of imperfect obligations would rule out precisely the domain of (human) rights as a foundation for CSR.

Hence, whichever interpretation we focus on when analyzing the alleged voluntariness of CSR, they all tend to elude the realm of rights. The first interpretation of voluntariness ascribes rights to the legal domain while perceiving CSR to be dealing with what is beyond the law. The second interpretation understands voluntariness as supererogation, which is at odds with the very concept of moral obligation as such. The third interpretation understands voluntariness as latitude contained in imperfect obligations, which does not per se exclude moral obligation from the realm of CSR, but limits them to those which are not rights-based. Thus, the conflict 
between conventional interpretations of CSR and the new debate on business and human rights crystallizes precisely around the following decisive difference: while CSR has traditionally focused on the domain of virtue and beneficence and thus may have tended to put the emphasis predominantly on what is desirable (and thus optional) rather than imperative, human rights claims deal with the indispensible and thus with what is owed to human beings; they are, in other words, located squarely in the realm of justice (see, e.g., Jones 2001; Pogge 2002; Wettstein 2009b).

The problem of non-political responsibility: as mentioned above, not all of the CSR debate is based on the voluntariness assumption. Consequently, the above explanation does not hold across the board. Nevertheless, the relative lack of attention paid to human rights can be observed not only for voluntary, but also for duty-based conceptions of CSR. Archie Carroll's (1979; see also Carroll and Buchholtz 2008) famous tripartite model of corporate responsibility is a case in point and similar claims can be made for most CSR conceptions rooted in "classic" stakeholder thinking. In fact, the criteria used for the selection of constituents that matter in most stakeholder approaches, as James Walsh (2005; see also Goodpaster 2010) showed, have prevented, rather than encouraged a focus on broad and general human rights issues such as, for example, the AIDS crisis. Moreover, granted that a focus on stakeholder relations may correct the overly narrow perspective of the shareholder value doctrine, but it does not per se imply or include a critique of the political philosophy of the firm as such. This, it seems, is a point that holds some validity for CSR in general; granted that the emphasis on a corporation's social responsibilities includes at least an implicit critique of a narrow, entirely economic interpretation of the corporation, but it does not fundamentally challenge the still common perception of the firm as a predominantly private institution. The clear division between the private and the public domain, which is characteristic for Western liberalism, is commonly accepted as an implicit assumption of conventional conceptions of CSR. Thus, while companies and their social responsibilities have been located in the private domain, human rights, by contrast, have traditionally been perceived as tools to curtail and limit political power; Their perceived addressees, as a consequence, are political, rather than private institutions. This interpretation partly overlaps with the first one discussed above: as vehicles for the protection against the abuse of political power, human rights were perceived as a part of the political or legal market frame for which not companies, but rather governments have been deemed responsible.

Recent developments under the banner of "corporate political activity" or "political CSR" (see Scherer and Palazzo 2011 for a comprehensive review of the respective literature), however, have started to call this clear separation between the private and public realm into question (see Cutler 1999; Kobrin 2009). Especially the lack of a comprehensive political and legal framework in the global arena, as Scherer and Palazzo argue has confronted multinational corporations in particular with the need to redefine their role and purpose in a deliberative manner and to deal with increasing expectations regarding their involvement in the development and enforcement of global rules and standards for the global market place (Scherer, Palazzo, and Baumann 2006, Scherer and Palazzo 2007). Not surprisingly, such political accounts of CSR are much more prone to ascribe an active role to business also in 
the protection and realization of rights (see, e.g. Matten and Crane 2005; Ulrich 2008; Scherer and Palazzo 2009) . Hence, while the tendency to interpret social responsibility apolitically partly explains the relative absence of human rights in the CSR debate in the past, the growing importance and influence of the new research on political CSR helps us understand the recent surge in human rights related contributions. Against this background, it comes as no surprise that the emergence of this new research coincides largely with the dawn of the third phase of respective contributions as outlined above.

To be sure, these elaborations ought not to imply that CSR has avoided or downright ignored human rights issues; in fact, many of the problems that CSR scholars are regularly dealing with are, at their core, human rights problems. Rather, the problem is that they have seldom truly been addressed as such (Campbell 2006: $256,260)$. For the reasons stated above, they have been addressed not in the terminology of justice, but often in that of virtue and beneficence or even philanthropy and charity. This not only sells CSR's own importance and relevance short, but it threatens to empty human rights of the moral urgency that constitutes and defines their very nature as the most fundamental claims and imperatives on the moral spectrum (Wettstein 2009a).

\section{INTEGRATING THE TWO DEBATES: POTENTIALS AND COMPLEMENTARITIES}

While especially the voluntariness assumption has obstructed the view on human rights from the standpoint of CSR, it is, on the flip side, the very reason why CSR is often perceived to be essentially about proactive corporate engagement in social causes and thus about corporate responsibilities beyond the (negative) realm of doing no harm. The strong focus on community relations and philanthropy of early approaches (Carroll 1999: 273), for example, included such proactive engagement of corporations by definition. Similarly, the above mentioned, more recent scholarship on political CSR has connected this proactive stance with questions of political responsibility and business involvement in collaborative solutions for global problems (see, e.g., Young 2003, 2004; Scherer and Palazzo 2007; Scherer, Palazzo, and Matten 2009). Finally, also newly emerging subfields such as the growing literature on business solutions for the base of the economic pyramid (see, e.g, Prahalad and Hart 2002; Prahalad and Hammond 2002; Prahalad 2005) or the related discussion on social innovation (see, e.g., Hart and Christensen 2002; Christensen, Baumann, Ruggles, and Sadtler 2006) and social entrepreneurship (Seelos and Mair 2005; Elkington and Hartigan 2008; see also Porter and Kramer's [2011] conception of "shared value") hinge on proactive company engagement.

Quite evidently, this focus contrasts sharply with the more restrictive perspective on wrongdoing that has characterized the business and human rights debate. Thus, while CSR has lacked a constitutive focus on people's rights, the business and human rights debate has lacked the focus on the positive potential of corporations to be a part of the solution rather than only a part of the problem when it comes to the prevailing challenges we are facing as a (global) society. 
Against this background, a closer integration of the two fields would come a long way in expanding their respective scope. With increasing influence, the legitimacy of the business and human rights debate hinges on bringing the normative-critical perspective back in. The broader debate on CSR can provide a productive venue for doing so. This, however, requires that the business and human rights debate broadens its perspective; it can no longer make do merely with focusing on the non-violation of human rights but must come up with answers regarding potential business responsibilities in the positive realm. On the other hand, if CSR ought to be plausible as a normative concept in the global age, it can no longer assign a merely peripheral role to human rights, but must put them at its very core.

Resulting from a combination and integration of the two debates, then, is an extended focus on proactive business involvement in the protection and realization of human rights - not as a matter of voluntariness or philanthropy, but as one of moral obligation. In other words, the integration of the two debates provides the space for the conceptualization of positive human rights obligations for corporations.

The above-mentioned debate on apartheid South Africa, which is located precisely in this intersection of CSR and human rights, can serve as a case in point in this regard. The Sullivan Principles in particular were geared not merely toward the non-violation of human rights in the workplace, but ascribed an active role to business in dismantling the apartheid laws in general (Williams 1986: 74). Di Norcia (1989: 869-70), for example, called for “[a]n activist MNC strategy against apartheid," demanding that they "must visibly represent human rights values" and "act as a conduit of the human rights ethic too." Looking back, Richard De George comments that corporations operating in South Africa at that time had a responsibility "to take active steps to undermine the government's unethical practices and laws." Furthermore, "Passive resistance was not enough; they had to be proactive in their approach, including promoting actions opposed to apartheid, pressuring the government to change its practices, publicizing their opposition to it, and supporting sanctions and other external attempts to influence the governments to change." (De George 2010: 420)

Against this background, the question we are facing is how to define, normatively, the space in which the two debates meet. This, in a nutshell, will be the task in the remainder of this contribution.

\section{CAPABILITY AND MORAL OBLIGATION: AN EXTENDED VIEW ON BUSINESS AND HUMAN RIGHTS}

Any human right, as Henry Shue argued in his seminal work on "Basic Rights" (1996), corresponds to a "tripartite typology of duties." For each right, as he argues, there are three types of correlating duties, "all of which must be performed if the basic right is to be fully honoured." (Shue 1996: 52) The three types of obligations are the duty to avoid depriving, the duty to protect from deprivation, and the duty to aid the deprived (Shue 1996: 52), or in slightly different terminology the duty to respect human rights, where our actions and life plans cross paths and potentially conflict with the life scripts of other human beings, the duty to protect human rights, 
where they are threatened by other human beings or institutions, and the duty to realize human rights where they have been violated or never been fulfilled. It is this typology that underlies also Ruggie's tripartite framework introduced earlier.

Human rights obligations of any agent can be framed in terms of these three categories. This does not imply that all agents have equally extensive obligations in each one of them. As Shue (1996: 52) notes, not all of these duties "must be performed by the same individuals or institutions," there is "the possibility of distributing each of the three kinds of duty somewhat differently." Thus, the question at the heart of the typology is how to adequately distribute the duties among potential duty-bearers.

Precisely in this question, Ruggie's restrictive approach is unconvincing both from a pragmatic and from a normative point of view. From a pragmatic point of view, predetermining the distribution of obligations between states and corporations (and all other powerful institutions, for that matter) in such a rigid way and ruling out any responsibility of corporations to proactively engage in the protection and realization of rights at the outset appears as unwise in the face of global problems that cannot be solved by governments, or indeed by any one agent acting alone (Nelson 2002: 2ff.; 2004: 24). In a world in which both the nature of problems and the patterns of influence and power have changed dramatically, holding on to traditional state-centrism in regard to the distribution of responsibility might prove counter-productive; it is prone to obscure and delay, rather than initiate and enforce innovative and viable solutions for the new kinds of challenges that we face. A more promising approach, it seems, would be to start with the assumption that all those agents with considerable power and unique and indispensible capabilities must naturally and at the outset bear their fair share of responsibility for finding solutions to prevailing human rights problems.

There is a growing number of (business) ethicists, moral or political philosophers, and also scholars in law and political science who have been advancing similar claims in support of this view. They all share in common the idea of separating remedial responsibility from a respective agent's prior involvement into bringing a problem about. The tenor among such accounts is that remedial responsibility grows proportionally to an agent's capabilities (Wettstein 2009b: 135-39), capacities (Miller 2005; Campbell 2006: 260), powers (Young 2003, 2004; Jonas 1984: 92ff.; Kobrin 2009: 350), leverage (Wood 2012), or their potential to have a positive impact on the situation (Santoro 2000: 143).

Arguably, the call for capability-based remedial obligations, which are detached from any prior involvement of a corporation in causing a problem, is not uncontroversial and may lead to misunderstandings, especially if taken out of the human rights context. Therefore, let me reiterate the specificity and sequence of my claim again. The argument that capability breeds positive, that is, remedial moral obligation hinges on the following presuppositions, some of which have been clarified in the course of this paper: first, human rights are moral claims and imperatives at the same time. In other words, the existence of a human right always implies a counterpart obligation ${ }^{10}$ for that right to be respected, protected, and realized. Second, while the negative duty to respect applies to everyone individually and equally and at all times, the positive duties to protect and to realize are, in a first instance, collective 
duties. It is the moral community of human beings as a whole that is obligated by the claims of its members whose rights are violated or remain unfulfilled. It should be undisputed that we, as a moral community, cannot grant human rights to all members, without accepting a collective obligation to strive toward their equal and universal fulfilment. Thus, as a moral community, we are obligated to create and maintain conditions and structures which are conducive to the equal and universal protection and realization of human rights. Each member, as a consequence, does not only have a duty not to undermine the realization of human rights (i.e. a duty to respect), but one to contribute to the collective task of furthering them within the bounds of reasonableness and their own capabilities (for a similar claim see Dubbink and van Lidekerke 2009: 132-33). Not all members of the community have equal capabilities to do so; some may be entirely powerless with little capacity to contribute at all. Thus, if this collective obligation is to carry any moral weight, then those who control the means and capabilities that are essential to the realization of the given task, are obligated at least prima facie to make them available to the moral community. Such prima facie obligations turn into final obligations if said actors are not able to produce valid reasons that would justifiably limit or eliminate such obligations.

Thus, the normative ground and foundation for remedial obligations in my argument are not capabilities, but the existence of human rights. The imperative deriving from human rights is what obligates in a first instance; capability is the criterion according to which to distribute this general, collective obligation among specific agents. Hence, I am not advancing a new form of "can implies ought" in my argument; it is not "can" that implies "ought," but the existence of human rights. Assigning this obligation to those with superior power and capabilities, then, corresponds to the widely accepted principle of "ought implies can," for the collective obligation which we bear as a moral community can be fulfilled only through a concerted effort by all those with the respective capabilities.

I hold such a capability-based model to be different from what is commonly called "noblesse oblige." While noblesse oblige tends to refer to a notion of private power deriving from wealth or financial potency and thus to associate responsibility with the realm of beneficence or charity, a capability-based model refers to the structural importance of corporate capability for the very constitution of today's global society. As such, we are dealing with public or political power and, correspondingly, not with noble gestures, but with genuine political responsibility. Thus, capability is linked precisely to the kind of political responsibility that has been identified above as one foundation based on which to connect human rights more closely with CSR.

The central challenge that such accounts of remedial corporate obligation are arguably faced with, as Hsieh (2004: 646) points out, is that of providing the grounds for their limitation. Thus, in order to be plausible, the "fair share" (Santoro) of responsibility of each responsible agent must be limited both in scope and extent. Propositions in regard to such limiting factors vary, although they do aim in the same general direction. Proximity (Campbell 2006: 260) or the requirement to be best placed to intervene (Miller 2005: 102) can be such limiting factors. Young's (2003: 42f.; 2004: 385ff.) "social connection model" goes further and complements power 
with connection and privilege as criteria that establish remedial obligations. Thus, the greater the power, the more direct the connection, and the greater the benefit an agent derives from a human rights violation, the greater its remedial responsibility and vice versa (see also the role of benefit in Hsieh's [2004: 650-51] "Principle of Limited Scope"). Similarly, in Santoro's (2000: 143-58; 2009: 14-17; 2010) "fair share theory of human rights responsibility" remedial obligations are dependent not only on the respective agents' potential to have a positive impact on the situation, but also on their relationship to the victims and their ability to withstand potential retaliation by the perpetrator. ${ }^{11}$

Hence, it is reasonable to assume that capability must be complemented with the requirement of a morally relevant connection in order to limit the scope of an agent's obligation and with the criterion of reasonableness of the normative burden (Miller 2005: 102; Ulrich 2008: 140) in order to limit the extent of the obligation. It is not the goal and aim of this paper to spell out a full-blown and comprehensive theory in this regard. Rather, its much more modest goal is to show that because capability obligates - at least in a prima facie sense-, corporate human rights obligations cannot plausibly be limited to the negative realm. It is against this background that I propose capability as a linchpin between CSR and the business and human rights debate based on which the formulation of positive human rights obligations for corporations becomes not only possible, but indeed plausible.

An agent's human rights obligations, then, crucially depend on its capabilities within the three categories of respecting, protecting, and realizing human rights. In the following, we will have a look at each one of these categories and how they relate to corporate capability. I will not spell out those obligations in detail, but rather aim at creating a general understanding of the nature of such capability-based human rights obligations.

\section{CORPORATE OBLIGATIONS TO RESPECT HUMAN RIGHTS}

Rather than asking us to actively perform certain actions, negative obligations to respect human rights command us not to act in certain ways, that is, to refrain from actions that may be harmful to other people. Any agent is obligated to not knowingly engage in activities that may contribute to the violation of another human being's rights. Because of the causal link between specific actions and the harm in which they result, such negative duties are universal; they apply to everyone in the same manner and to the same extent. Therefore, from a moral point of view, there is no plausible argument why corporations should be exempt from them.

This does not only concern direct human rights violations of corporations, but also and perhaps especially indirect ones, i.e. cases in which corporations are not the primary perpetrators, but rather aid and abet human rights abuse committed by third parties such as host governments or suppliers and contractors in the company's value chain. After all, the majority of cases of corporate involvement in human rights violations today are indirect (Kobrin 2009). Against this background, it is not surprising that corporate complicity has played an increasingly prominent role within the business and human rights debate. ${ }^{12}$ Despite that, however, little attention 
has been paid to the normative implications of the concept so far. Especially the line between duties to respect and duties to protect blurs considerably in the case of indirect human rights violations. As such, the concept poses a direct challenge to the current state of the art in business and human rights, which categorically limits corporate obligations to the negative realm of the duty to respect.

\section{CORPORATE OBLIGATIONS TO HELP PROTECT HUMAN RIGHTS}

To limit corporate human rights obligations to the category of the duty to respect frequently falls short when dealing with cases of corporate complicity. Take the sweatshop example again; the negative duty to respect human rights would imply that corporations, which detect exploitation and abuse in their value chains, immediately end their business relations with the respective contractors. However, more often than not, such a solution would be morally unsatisfactory. Increasingly, what we expect from corporations is that within the range of their capabilities they use their leverage (Wood 2012) to put pressure on suppliers and contractors to improve their working conditions rather than merely to abandon them. In other words, increasingly, what is expected of corporations in such situations, is that they protect the workers of contractors from the abuse, rather than to merely demonstrate their respect for human rights by cutting their ties with the violators.

Similar conclusions can be drawn in regard to the broader political context. With growing power and influence the capabilities of multinational corporations to put pressure even on oppressive host governments have increased and increasingly companies are expected to do just that. Refusal to make use of their leverage in such situations may be interpreted as a sign of moral support and approval, which is frequently interpreted as a form of moral complicity (Howen 2005a: 15; Clapham and Jerbi 2001: 344; Wettstein 2010; 2012). For Sir Geoffrey Chandler (1999: 43) it is a "wholly legitimate role" for today's large and powerful corporations "to speak out in defence of human rights where they are violated in the countries in which they work." Also Tom Campbell (2006: 258) sees it as "a part of the obligations of MNCs to do what they can to place pressure on abusive governments" when human rights are at stake. Michael A. Santoro (2000; 2009), finally, has written extensively on how corporations not only can, but should, influence social and political change in authoritarian regimes with questionable human rights records. ${ }^{13}$

Such political activity of corporations in defense of human rights should not be misunderstood as illegitimate interference with the internal affairs of the respective countries. Human rights are not an internal affair to begin with, but an imperative that humanity itself places universally on all governments. A corporation which is in a position to put pressure on governments which systematically sideline this fundamental obligation may justifiably face the accusation of complicity if it fails to take a stance in favor of human rights. It is important to note that their growing power exposes such companies in public and political roles irrespective of whether or not they are in fact taking an explicit stance. Silence, in such cases, is not neutral but a form of condoning the abuse; the perception that speaking out is interfering with domestic politics while keeping quiet is politically neutral, as a consequence, is 
inherently flawed. Thus, Chandler (1999: 43) was right in warning companies from using the interference argument as an "escape route" to remain passive. ${ }^{14}$

Today, multinational corporations' new political stature is tested perhaps most profoundly in their relation to the Chinese government. In the struggle for the best positions in tapping the vast potential of the fast growing Chinese market, human rights have often taken a back-seat in corporate agendas. Google's recent confrontation of the Chinese government over censorship rules and a number of cyber attacks on the e-mail accounts of human rights activists, however, may signal a shift in attitude. Google's move, which was applauded by human rights organizations, represents much more than an attempt to "do no evil." At its core, it is the acknowledgment of their growing political relevance and power on the world stage and of the human rights responsibilities that derive from it.

The compromise between the Chinese government and Google that was reached over the issue was perceived by The New York Times as a solution "which allows both China and Google to claim victory" (Barboza and Helft 2010). By any means, this does not put Google on equal footing with the Chinese government, but it is a reflection of a power balance that is shifting profoundly. Xiao Qiang, director of the China Internet Project at the University of California, Berkeley, commented in the same New York Times article that "It is unprecedented for a private company to challenge Chinese Internet censorship. . . . In the past, there would have been no doubt that the Chinese government would have punished Google." The dispute between Google and the Chinese government may give us a taste of how powerful today's large multinationals have become; such power must be accompanied by an enlarged responsibility for the protection and realization of human rights.

\section{CORPORATE OBLIGATIONS TO REALIZE HUMAN RIGHTS}

The third category of corporate human rights obligations deals with the realization of unfulfilled human rights claims and thus typically with so-called second generation social and economic human rights. The normative problem connected to assigning responsibility for such rights is twofold. First, as Henry Shue (1988: 690) pointed out, they demand full coverage without, however, giving rise to universal duties. Thus, they "need to be divided up and assigned among bearers in some reasonable way." (Shue 1988: 690) As such, their fulfillment by definition depends on collaborative solutions involving a variety of different agents and agencies. Second, the violation of socio-economic rights often - although not always-is the result of complex systemic interactions between a wide variety of different agents. This is precisely what makes it difficult, if not impossible, to assign remedial responsibility based on an agent's involvement in bringing the human rights problem about. When involvement ceases to provide a reliable guide to allocate remedial responsibility, however, we must turn to capability.

While we can assume that unique and essential capabilities lead to remedial obligations of some sort, the question of what constitutes a reasonable contribution by an agent cannot be answered detached from the particular context in which it unfolds. Thus, while capability obligates in terms of remedial contributions, it does 
so "merely" in a prima facie sense. In a first instance, then, the presumption of such prima facie remedial obligations creates a derivative responsibility for the respective agents to engage and participate in exploratory multi-stakeholder dialogues which aim at the clarification, definition, and division of the subsequent remedial obligations. Because prima facie we can assume the existence of capability-based remedial obligations, the respective agents cannot forego them simply by withholding their participation in exploratory dialogues. However, it seems that this is precisely what corporations have tended to do in the past; with few exceptions - the Business Leaders Initiative on Human Rights (BLIHR) may be the most notable and progressive one among them-they have stalled rather than promoted respective efforts to clarify and define their own role and obligations in regard to human rights.

Some may oppose such arguments by disputing the very quality and status of socio-economic rights as genuine human rights. However, if we care about the autonomy and inherent dignity of human beings in all their dimensions, the sole reliance on liberty rights is insufficient; equally important are those rights that secure the positive conditions of human freedom. It is often overlooked that the rights connected to such positive freedoms - the right to health, to food, to an adequate standard of living, etc. - are in many respects even more basal than the classic liberty rights. A closer look at the relation between these categories of rights shows, for example, that liberty without the existence of any real opportunities makes a mockery of human freedom. It shows that people can be free from interference, but still suffer or even die from hunger and illness. It shows that liberty without justice and real opportunity is no more than a mask for indifference and carelessness. "Without minimal standards of subsistence," as Onora O'Neill (2000: 134) rightly argues in this context, "agency itself fails, and so the point of liberty of action and hence even of liberty rights is gone."

Social and economic rights are not mere add-ons to more fundamental liberty rights. Quite the contrary, they are the very condition to make use of one's liberty in the first place. As such, their moral status and with it their general moral imperative is at least equal to that of classical liberty rights. As Henry Shue (1996: 8) argues, "there are ... some economic rights over which no other rights have priority." They are, in other words, genuine human rights. Consequently, at least those attempts to refute positive obligations of corporations for the realization of socio-economic rights on the basis of their allegedly weaker ethical standing than liberty rights must necessarily fail.

Concordantly, Justine Nolan and Luke Taylor (2009) are quite right in arguing that also corporate human rights obligations must not be limited merely to liberty rights, but must be extended to cover socio-economic rights as well. This is not disputed even by John Ruggie. In fact, one of the major insights of the 2008 reports precisely is that corporate obligations should not be derived "from a limited list of human rights for which companies would have responsibility," but arise "in relation to all rights" that companies might impact (United Nations 2008b: 4). Granted that this seems indeed the right approach to take, but Ruggie's subsequent limitation of corporate obligation to mere non-violation-what I have called "human rights minimalism" above—is little helpful especially in the case of socio-economic rights 
whose violation often occurs as a result of structural processes that offer little possibility to hold anyone liable at the outset. The very distinction between respecting and protecting and thus between negative and positive obligations, as also Nolan and Taylor (2009: 443) argue, gets "tenuous and murky" in the domain of socioeconomic rights. In any case, a purely negative duty to respect such rights, while arguably helping to prevent a situation from getting worse, will do little to actually improve the situation of the masses whose rights remain unrealized today. To limit corporate duties for such rights at the outset and per se to the negative realm of non-violation means to put the prospect of achieving holistic collaborative solutions for today's large-scale human rights challenges in serious jeopardy by letting one of the most powerful parties in the mix off the hook.

The fact that such capability-based duties necessarily leave room for interpretation and deliberation and are, as such, notoriously hard to define is a rather weak argument for refuting their existence and justification altogether. If anytime we face that most common moral philosophical question of "where to draw the line," we were to drop our demand for holding the respective agents responsible rather than to engage in serious deliberation, we would end up in a moral vacuum rather sooner than later. The world is becoming an increasingly complex place, where more and more agents and agencies share powers and responsibilities, both in complementary and overlapping ways. In this environment, we better get used to dealing and struggling with the question of where to draw that line, for it increasingly denotes the rule, rather than the exception.

\section{CONCLUSION}

In a 2007 publication, commenting on "future directions" of the business and human rights debate, John Ruggie stated that its focal point "needs to expand beyond establishing individual corporate liability for wrongdoing." "An individual liability model alone," as he went on to justify his claim, "cannot fix larger imbalances in the system of global governance." (Ruggie 2007: 839) Unfortunately, such visionary thinking is largely missing in the 2008 reports-the focus precisely on corporate liability for wrongdoing dominates the tenor of the reports. Normative CSR research, as I have argued in this article, would provide a space to reclaim some of this visionary potential.

It makes sense both from a normative and a practical perspective to start (although not limit) our reflections on CSR with a focus on human rights. Against the background of a rapidly globalizing world, the justification of (responsible) business practices across borders and cultures is turning into an immediate practical concern. Against this background, the universal foundation of human rights makes them an attractive normative ideal also from a practical point of view. In the struggle to find common ground between different cultural and moral traditions, the inter-subjective, universal justifiability of human rights provides a platform which other perspectives cannot, or only insufficiently, match. If nothing else, human rights provide a basis on which the practical discussion of global responsibilities effectively becomes possible. This is of particular importance once we enter the contentious domain of 
potential obligations of the positive kind. It makes good sense for corporations to adopt the language of human rights when deliberating such responsibilities. After all, the requirement of universal justification does not only create, but also limit corresponding moral obligations.

Formulating holistic models that address human rights questions in a more systematic way must become a core concern in CSR. A comprehensive political or legal framework to hold multinationals accountable at least for their negative duties to respect human rights will surely be inevitable in the long run. However, of particular importance will be how such models deal with socio-economic rights. If the failure of the UN Draft Norms and the history of failed attempts before them are any indication, the obstacles for institutionalizing also positive duties to protect and to realize human rights in a similar way may prove insurmountable for the foreseeable future. Thus, at least in the short run, we need to find ways to make proactive company engagement plausible to business as genuine moral obligations, that is, as requirements beyond voluntariness and moral discretion or the mere prospect of economic gain.

The best bet to do so for CSR is to start (re-)emphasizing the question of purpose and mission of businesses. Positive moral obligations are, at their core, grounded teleologically. In other words, if positive obligations ought to matter to business, they must be attached to and indeed become part of their very purpose, of their vision and mission, that is, of the very reason they are in business. The above-mentioned discussions on business solutions for the bottom of the economic pyramid (BOP) or on social innovation and social entrepreneurship hold much promise, but they must be tied much more closely to moral obligation rather than relying solely on the prospect of economic gain. It is the shortcoming of these new debates that they have not been cast sufficiently in a normative light — the avenue of human rights can provide this missing perspective and indeed a foundation for doing so.

It is the very identity of business that is at stake here. It is in this particular aspect that the task before us transcends the question of mere corporate responsibility; ultimately, achieving purpose in business requires business leaders with a professional identity, that is, leaders with a sense of purpose and a professional ethos. They must see it as a part of their agenda to better the conditions of those in need and to make real contributions to a more sustainable development of our global society. We, as scholars and teachers, can make our biggest contribution through fostering and promoting such professional identities in our MBA classrooms. 


\section{NOTES}

I would like to thank three anonymous reviewers for their thoughtful comments on earlier versions of this manuscript. Special thanks go to Guido Palazzo for his guidance through the process and for investing much time and effort to help me improve this paper.

1. For the sake of this paper, I will take the work of the SRSG as representative for the state of the art of the debate, since it has come to be increasingly influential and indeed dominant in terms of setting the agenda and new standards for the debate.

2. I will abstain from engaging in a lengthy discussion of the relevance of moral rights as a concept. The idea of moral rights was famously dismissed as "nonsense upon stilts" by Jeremy Bentham (2002: 317). In the contemporary debate, Jürgen Habermas takes a critical position especially on human rights as moral rights. For Habermas (1998: 191), a human right "does not have its origins in morality, but rather bears the imprint of the modern concept of individual liberties, hence of a specifically juridical concept." However, also Habermas (1998: 191) argues that while human rights are not moral rights in the sense put forth in this contribution, they can be justified exclusively from a moral point of view. For the sake of this article, I will side with Joel Feinberg's position without further elaboration. For Feinberg (1973: 84), any theory of the nature of rights that cannot account for moral rights "is radically defective." See also Feinberg's three-tiered defence of moral rights in Freedom and Fulfillment (1992: 197-259).

3. In the third category, Ruggie essentially deals with grievance mechanisms for those who have been harmed by corporate activities. He interprets such mechanisms both as a part of the state duty to protect as well as the corporate duty to respect and thus as a sub-category or a derivative of the first two categories of human rights obligations.

4. The International Council on Human Rights Policy, for example, states that "Whether they are direct or indirect, obligations need to be enforced if they are to be of real use. A discussion of legal human rights obligations would be incomplete if it did not consider the different legal mechanisms that can be used to enforce them" (ICHRP 2002: 3).

5. The 2010 Society for Business Ethics Annual Meeting in Montreal, for example, featured three sessions on business and human rights.

6. A Business Ethics Quarterly special issue on business and human rights was published in January 2012; the Journal of Business Ethics published a special issue on the topic in 2009.

7. It is perhaps symptomatic that also in the current phase many of the contributions which explicitly aim at connecting the business and human rights debate with the concept of CSR are written by legal scholars. As a consequence, they often suffer from the limitations pointed out in the previous section (see, e.g., McCorquodale 2009; Buhmann 2009; Mayer 2009; see, earlier, Frey 1997).

8. Based on the elaboration of Morrell Heald (1970), Carroll speaks of a preoccupation of business with philanthropy and community relations before the 1970s.

9. For example, the perception of CSR underlying Porter and Kramer's (2011: 16) recent critique comes close to reflecting such an understanding of voluntariness.

10. Kant (1996: 30), for example, defined rights as "(moral) capacities for putting others under obligations."

11. In a recent contribution, Bishop (2012) proposed that human rights obligations of business in general are naturally limited by the set of legal rights we are willing to grant them, since a basic condition for the fulfillment of an obligation is having the necessary rights to do so.

12. To define and clarify the implications of the concept of complicity for (multinational) companies was the explicit mandate of the SRSG during his first tenure. The "final" report containing his findings in this regard was released in Summer 2008 (See United Nations 2008a). For a broad overview over the debate on corporate complicity in human rights violations, see Clapham and Jerbi 2001; Clapham 2004; Wells and Elias 2005; Howen 2005a; Ramasastry 2002; Brenkert 2009; and Hoffman and McNulty 2009.

13. However, Santoro (2000: 156) favors influence based on action, rather than on words: "The vast majority of corporate executives simply aren't very good at understanding the various nuances of human rights controversies. As a result, they are unlikely to be effective as vocal critiques of general human rights conditions in their host countries. For multinational corporations, actions speak louder than words."

14. See Hsieh 2009 for a more systematic refutation of the interference objection. 


\section{REFERENCES}

Alston, P. 2005. Non-State Actors and Human Rights. Oxford: Oxford University Press.

Amnesty International. 1998. Human Rights Principles for Companies. New York: Amnesty International. AI Index ACT 70/01/98.

Andiappan, P., M. Reavley, and S. Silver. 1990. "Discrimination against Pregnant Employees: An Analysis of Arbitration and Human Rights Tribunal Decisions in Canada," Journal of Business Ethics 9(2): 143-49.

Andreopoulos, G., Z. F. K. Arat, and P. Juviler. 2006. Non-State Actors in the Human Rights Universe. Bloomfield, Conn.: Kumarian Press.

Arnold, D. G. 2003a. "Human Rights and Business: An Ethical Analysis," in Business and Human Rights: Dilemmas and Solutions, ed. R. Sullivan, 69-81. Sheffield: Greenleaf Publishing.

2003b. "Moral Reasoning, Human Rights, and Global Labor Practices," in Rising above Sweatshops: Innovative Approaches to Global Labor Challenges, ed. L. P. Hartman, D. G. Arnold, and R. E. Wokutch, 77-99. Westport, Conn.: Praeger.

2010. "Transnational Corporations and the Duty to Respect Basic Human Rights," Business Ethics Quarterly 20(3): 371-99.

Arnold, D. G., and N. E. Bowie. 2003. "Sweatshops and Respect for Persons," Business Ethics Quarterly 13(2): 221-42.

Arnold, D. G., and L. P. Hartman. 2006. "Worker Rights and Low Wage Industrialization: How to Avoid Sweatshops," Human Rights Quarterly 28(3): 676-700.

Avery, C. L. 2000. Business and Human Rights in a time of change. London: Amnesty International UK.

Barboza, D., and M. Helft. 2010. "A Compromise Allows Both China and Google to Claim Victory," The New York Times (July 10).

Bentham, J. 2002. "Rights, Representation, and Reform: Nonsense Upon Stilts and Other Writings on the French Revolution," in The Collected Works of Jeremy Bentham, ed. P. Schofield, C. Pease-Watkin, and C. Blamers. Oxford: Clarendon Press.

Bhagwati, J. 2004. In Defense of Globalization. Oxford: Oxford University Press.

Bishop, J. D. 2012. "The Limits of Corporate Human Rights Obligations and the Rights of For-Profit Corporations," Business Ethics Quarterly 22(1): 119-44.

Brenkert, G. G. 1992. “Can We Afford International Human Rights?,” Journal of Business Ethics 11(7): 515-21.

. 2009. "Google, Human Rights, and Moral Compromise," Journal of Business Ethics 85(4): 453-78.

Buhmann, K. 2009. "Regulating Corporate Social and Human Rights Responsibilities at the UN Plane: Institutionalising New Forms of Law and Law-making Approaches?," Nordic Journal of International Law 78(1): 1-52.

Campbell, T. 2006. "A Human Rights Approach to Developing Voluntary Codes of Conduct for Multinational Corporations," Business Ethics Quarterly 16(2): 255-69.

Carroll, A. B. 1979. "A Three-Dimensional Conceptual Model of Corporate Performance," Academy of Management Review 4(4): 497-505. 
1999. "Corporate Social Responsibility: Evolution of a Definitional Construct," Business and Society 38(3): 268-95.

Carroll, A. B., and A. K. Buchholtz. 2008. Business and Society. Ethics and Stakeholder Management. Mason, Ohio: South-Western.

Cassel, D. 2001. "Human Rights and Business Responsibilities in the Global Marketplace," Business Ethics Quarterly 11(2): 261-74.

Chandler, G. 1998. "Oil Companies and Human Rights," Business Ethics: A European Review 7(2): 69-72.

1999. "Keynote Address: Crafting a Human Rights Agenda for Business," in Human Rights Standards and the Responsibility of Transnational Corporations, ed. M. K. Addo, 39-45. The Hague: Kluwer Law International.

. 2003. "The Evolution of the Business and Human Rights Debate," in Business and Human Rights: Dilemmas and Solutions, ed. R. Sullivan, 22-32. Sheffield: Greenleaf Publishing.

Christensen, C. M., H. Baumann, R. Ruggles, and T. M. Sadtler. 2006. "Disruptive Innovation for Social Change," Harvard Business Review 84(12): 94-101.

Clapham, A.1993. Human Rights in the Private Sphere. Oxford: Clarendon Press.

. 2004. "State Responsibility, Corporate Responsibility, and Complicity in Human Rights Violations," in Responsibility in World Business. Managing Harmful Side-effects of Corporate Activity, ed. L. Bomann-Larsen and O. Wiggen, 50-81. Tokyo: United Nations University.

2006. Human Rights Obligations of Non-State Actors. Oxford: Oxford University Press.

Clapham, A., and S. Jerbi. 2001. "Categories of Corporate Complicity in Human Rights Abuses," Hastings International and Comparative Law Review 24: 339-50.

Commission of the European Communities. 2006. "Communication from the Commission to the European Parliament, the Council and the European Economic and Social Committee." Implementing the Partnership for Growth and Jobs: Making Europe a Pole of Excellence on Corporate Social Responsibility. Brussels, March 22, 2006.

Cragg, W. 2000. "Human Rights and Business Ethics: Fashioning a New Social Contract," Journal of Business Ethics 27(1,2): 205-14.

2010. "Business and Human Rights: A Principle and Value-Based Analysis," in The Oxford Handbook of Business Ethics, ed. G. G. Brenkert and T. L. Beauchamp, 267-304. Oxford: Oxford University Press.

. 2012. "Ethics, Enlightened Self-Interest, and the Corporate Responsibility to Respect Human Rights: A Critical Look at the Justificatory Foundations of the UN Framework," Business Ethics Quarterly 22(1): 9-36.

Cutler, A. C. 1999. "Locating 'Authority' in the Global Political Economy," International Studies Quarterly 43(1): 59-81.

De George, R. T. 2010. Business Ethics, 7th ed. Upper Saddle River, N.J.: Prentice Hall.

Di Norcia, V. 1989. “The Leverage of Foreigners: Multinationals in South Africa,” Journal of Business Ethics 8(11): 865-71. 
Donaldson, T. 1989. The Ethics of International Business. Oxford: Oxford University Press.

2003. "De-Compacting the Global Compact," Journal of Corporate Citizenship 11: 69-72.

Donnelly, J. 2003. Universal Rights in Theory and Practice. Ithaca, N.Y.: Cornell University Press.

Dubbink, W., and L. van Liedekerke. 2009. "A Neo-Kantian Foundation of Corporate Social Responsibility," Ethical Theory and Moral Practice 12(2): 117-36.

Elkington, J., and P. Hartigan. 2008. The Power of Unreasonable People: How Social Entrepreneurs Create Markets that Change the World. Boston: Harvard Business Press.

European Commission. 2001. Promoting a European Framework for Corporate Social Responsibility: Green Paper. Luxembourg: Office for Official Publication of the European Communities.

Feinberg, J. 1973. Social Philosophy. Englewood Cliffs, N.J.: Prentice Hall. 1980. Rights, Justice, and the Bounds of Liberty. Essays in Social Philosophy. Princeton, N.J.: Princeton University Press.

1992. Freedom and Fulfillment. Princeton, N.J.: Princeton University Press.

Forcese, C. 2001. "ATCA's Achilles Heel: Corporate Complicity, International Law and the Alien Tort Claims Act," Yale Journal of International Law 26: 487-515.

Frankena, W. K. 1973. Ethics, 2nd ed. Englewood Cliffs, N.J.: Prentice Hall.

Frankental, P. 2002. "The UN Universal Declaration of Human Rights as a Corporate Code of Conduct," Business Ethics: A European Review 11(2): 129-33.

Frankental, P., and F. House. 2000. Human Rights—Is It Any of Your Business? London: Amnesty International UK and The Prince of Wales Business Leaders Forum.

Frey, B. A. 1997. "The Legal and Ethical Responsibilities of Transnational Corporations in the Protection of International Human Rights," Minnesota Journal of Global Trade 6: $153-88$.

Gibney, M., and S. Skogly. 2010. Universal Human Rights and Extraterritorial Obligations. Philadelphia: University of Pennsylvania Press.

Goodpaster, K. E. 2010. "Corporate Responsibility and Its Constitutents," in The Oxford Handbook of Business Ethics, ed. G. G. Brenkert and T. L. Beauchamp, 126-57. Oxford: Oxford University Press.

Habermas, J. 1998. "Kant's Idea of Perpetual Peace: At Two Hundred Years' Historical Remove," in The Inclusion of the Other: Studies in Political Theory, ed. C. Cronin and P. De Greiff, 165-202. Cambridge, Mass.: MIT Press.

Hart, S. L., and C. M. Christensen. 2002. "The Great Leap: Driving Innovation from the Base of the Pyramid," Sloan Management Review 44(1): 51-56.

Heald, M. 1970. The Social Responsibilities of Business: Company and Community 1900 1960. Cleveland: The Press of Case Western Reserve University.

Hindman, H. D., and C. G. Smith. 1999. "Cross-Cultural Ethics and the Child Labor Problem," Journal of Business Ethics 19(1): 21-33. 
Hoffman, W. M., and R. E. McNulty. 2009. "International Business, Human Rights, and Moral Complicity: A Call for a Declaration on the Universal Rights and Duties of Business," Business and Society Review 114(4): 541-70.

Howen, N. 2005a. "Responsibility and Complicity from the Perspective of International Human Rights Law," in The 2005 Business and Human Rights Seminar Report: Exploring Responsibility and Complicity, ed. M. Shinn, 12-15. London: Business and Human Rights Seminar Ltd.

. 2005b. "'Voluntary or Mandatory: This Is (Not) the Question': A Comment," Zeitschrift für Wirtschafts- und Unternehmensethik 6(3): 321-23.

Hsieh, N. 2004. "The Obligations of Transnational Corporations: Rawlsian Justice and the Duty of Assistance," Business Ethics Quarterly 14(4): 643-61.

. 2009. "Does Global Business Have a Responsibility to Promote Just Institutions?," Business Ethics Quarterly 19(2): 251-73.

Human Rights Watch. 1999a. The Enron Corporation: Corporate Complicity in Human Rights Violations. New York: Human Rights Watch. http://www.hrw.org/ reports/1999/enron/.

1999b. The Price of Oil: Corporate Responsibility and Human Rights Violations in Nigeria's Oil Producing Communities. New York: Human Rights Watch. http://www.hrw.org/reports/1999/nigeria/.

International Chamber of Commerce / International Organization of Employers (ICC/IOE). 2004. Joint Views of the IOE and ICC on the Draft "Norms on the Responsibilities of Transnational Corporations and Other Business Enterprises with Regards to Human Rights. Paris; Geneva: ICC, IOE. http://www.reports-and-materials.org/IOE -ICC-views-UN-norms-March-2004.doc

International Council on Human Rights Policy (ICHRP). 2002. Beyond Voluntarism: Human Rights and the Developing International Legal Obligations of Companies. Versoix: International Council on Human Rights Policy.

International Labour Office. 2007. The Promotion of Sustainable Enterprises. Report VI. International Labour Conference, 96th Session, Geneva. http://www.ilo.org/dyn/ empent/docs/F1377429635/ILCSustainableEnterprises.pdf.

Jonas, H. 1984. The Imperative of Responsibility: In Search of an Ethics for the Technological Age. Chicago: University of Chicago Press.

Jones, C. 2001. Global Justice: Defending Cosmopolitanism. Oxford: Oxford University Press.

Jonker, J. 2005. “CSR Wonderland: Navigating between Movement, Community, and Organization," Journal of Corporate Citizenship 20: 19-22.

Jungk, M. 2000. Deciding Whether to Do Business in States with Bad Governments. Copenhagen: The Danish Centre for Human Rights.

. 2001. Defining the Scope of Business Responsibility for Human Rights Abroad. Copenhagen: The Danish Centre for Human Rights.

Kant, I. 1996. The Metaphysics of Morals, trans. Mary Gregor. Cambridge: Cambridge University Press. 
Kobrin, S. J. 2009. "Private Political Authority and Public Responsibility: Transnational Politics, Transnational Firms and Human Rights," Business Ethics Quarterly 19(3): 349-74.

Kurlantzick, J. 2004. "Taking Multinationals to Court: How the Alien Tort Act Promotes Human Rights,” World Policy Journal 21(1): 60-67.

Leisinger, K. M. 2003. "Opportunities and Risks of the United Nations Global Compact: The Novartis Case Study," Journal of Corporate Citizenship 11: 113-31.

Maitland, I. 2004. "The Great Non-Debate Over International Sweatshops," in Ethical Theory and Business (7th edition), ed. T. L. Beauchamp and N. Bowie, 597-607. Englewood Cliffs, N.J.: Prentice Hall.

Margalit, A. 1996. The Decent Society. Cambridge, Mass.: Harvard University Press.

Mathews, J. T. 1997. "Power Shift," Foreign Affairs 76(1): 50-66.

Matten, D., and A. Crane. 2005. "Corporate Citizenship: Toward an Extended Theoretical Conceptualization," Academy of Management Review 30(1): 166-79.

Mayer, A. E. 2009. "Human Rights as a Dimension of CSR: The Blurred Line Between Legal and Non-Legal Categories," Journal of Business Ethics 88: 561-77.

McCorquodale, R. 2009. "Corporate Social Responsibility and International Human Rights Law," Journal of Business Ethics 87(2): 385-400.

McCorquodale, R., and P. Simons. 2007. "Responsibility beyond Borders: State Responsibility for Extraterritorial Violations by Corporations of International Human Rights Law," The Modern Law Review 70(4): 598-625.

Mena, S., M. de Leede, D. Baumann, N. Black, S. Lindeman, and L. McShane. 2010. "Advancing the Business and Human Rights Agenda: Dialogue, Empowerment, and Practical Engagement," Journal of Business Ethics 93(1): 161-88.

Meyer, W. H. 2003. "Activism and Research on TNCs and Human Rights: Building a New International Normative Regime," in Transnational Corporations and Human Rights, ed. J. G. Frynas and S. Pegg, 33-52. New York: Palgrave Macmillan.

Mill, J. S. 2001. Utilitarianism. Indianapolis: Hackett Publishing Company, Inc.

Miller, D. 2005. "Distributing Responsibilities," in Global Responsibilities: Who Must Deliver on Human Rights?, ed. A. Kuper, 95-115. New York: Routledge.

Monshipouri, M., C. E. Welch, and E. T. Kennedy. 2003. "Multinational Corporations and the Ethics of Global Responsibility: Problems and Possibilities," Human Rights Quarterly 25(4): 965-89.

Muchlinski, P. 2001. "Human Rights And Multinationals: Is There A Problem?," International Affairs 77(1): 31-47.

. 2012. "Implementing the New Corporate Human Rights Framework," Business Ethics Quarterly 22(1): 145-77.

Munchus, G. 1989. "Testing as a Selection Tool: Another Old and Sticky Managerial Human Rights Issue," Journal of Business Ethics 8(10): 817-20.

Nelson, J. 2002. Building Partnerships: Cooperation between the United Nations System and the Private Sector. New York: United Nations. 
2004. "The Public Role of the Private Enterprise: Risks, Opportunities, and New Models of Engagement," Working Paper of the Corporate Social Responsibility Initiative. Cambridge, Mass.: John F. Kennedy School of Government.

Nolan, J., and L. Taylor. 2009. "Corporate Responsibility for Economic, Social and Cultural Rights: Rights in Search of a Remedy?," Journal of Business Ethics 87(2): 433-51.

Nussbaum, M. C. 2002. "Capabilities and Human Rights," in Global Justice and Transnational Politics: Essays on the Moral and Political Challenges of Globalization, ed. P. De Greiff and C. Cronin, 117-49. Cambridge, Mass.: The MIT Press.

Oliver, D., and J. Fedtke. 2007. Human Rights and the Private Sphere: A Comparative Study. London: Routledge-Cavendish.

O’Neill, O. 1996. Towards Justice and Virtue: A Constructive Account of Practical Reasoning. Cambridge: Cambridge University Press.

2000. Bounds of Justice. Cambridge: Cambridge University Press.

Palazzo, G., and A. G. Scherer. 2009. "Entfesselung und Eingrenzung - Konsequenzen einer global entfesselten ökonomischen Vernunft für die soziale Verantwortung der Unternehmen," in Markt, Mensch und Freiheit: Wirtschaftsethik in der Auseinandersetzung, ed. M. Breuer, P. Mastronardi, and B. Waxenberger: 81-95. Bern: Haupt.

Pegg, S. 2003. "An Emerging Market for the New Millennium: Transnational Corporations and Human Rights," in Transnational Corporations and Human Rights, ed. J. G. Frynas and S. Pegg. Houndsmills: Palgrave Macmillan.

Pogge, T. W. 2002. World Poverty and Human Rights. Cambridge.: Polity Press.

Porter, M. E., and M. R. Kramer. 2011. "Creating Shared Value: How to Reinvent Capitalism-and Unleash a Wave of Innovation and Growth," Harvard Business Review 89(1,2): 62-77.

Post, J. 1985. "Assessing the Nestle Boycott: Corporate Accountability and Human Rights," California Management Review 27(2): 113-31.

Powell, B. 2006. "In Reply to Sweatshop Sophistries," Human Rights Quarterly 28(4): 1031-42.

Prahalad, C. K. 2005. The Fortune at the Bottom of the Pyramid: Eradicating Poverty through Profits. Upper Saddle River, N.J.: Wharton School Publishing.

Prahalad, C. K., and A. Hammond. 2002. "Serving the World's Poor Profitably," Harvard Business Review 80(9): 48-57.

Prahalad, C. K., and S. L. Hart. 2002. “The Fortune at the Bottom of the Pyramid,” Strategy and Business 26: 2-14.

Radin, T. J., and M. Calkins. 2006. "The Struggle against Sweatshops: Moving Toward Responsible Global Business," Journal of Business Ethics 66(2,3): 261-72.

Ramasastry, A. 2002. "Corporate Complicity: From Nuremberg to Rangoon; An Examination of Forced Labor Cases and Their Impact on the Liability of Multinational Corporations," Berkeley Journal of International Law 20(1): 91-159.

Ratner, S. R. 2001. "Corporations and Human Rights: A Theory of Legal Responsibility," The Yale Law Journal 111(3): 443-545. 
Robinson, M. 2003. "Foreword," in Business and Human Rights: Dilemmas and Solutions, ed. R. Sullivan, 9-12. Sheffield: Greenleaf Publishing.

Ruggie, J. G. 2007. "Business and Human Rights: The Evolving International Agenda," American Journal of International Law 101: 819-40.

Santoro, M. A. 2000. Profits and Principles. Global Capitalism and Human Rights in China. Ithaca, N.Y.: Cornell University Press.

2003a. "Beyond Codes of Conduct and Monitoring: An Organizational Integrity Approach to Global Labor Practices," Human Rights Quarterly 25(2): 407-24.

. 2003b. "How Nongovernmental Organizations and Multinational Enterprises Can Work Together to Protect Global Labor Rights," in Rising above Sweatshops: Innovative Approaches to Global Labor Challenges, ed. L. P. Hartman, D. G. Arnold, and R. E. Wokutch, 101-18. Westport, Conn.: Praeger.

2009. China 2020. How Western Business Can-and Should-Influence Social and Political Change in the Coming Decade. Ithaca, N.Y.: Cornell University Press.

2010. "Post-Westphalia and Its Discontents: Business, Globalization, and $\mathrm{Hu}-$ man Rights in Political and Moral Perspective," Business Ethics Quarterly 20(2): 285-97.

Scherer, A. G., and G. Palazzo. 2007. "Toward a Political Conception of Corporate Responsibility: Business and Society Seen from a Habermasian Perspective," Academy of Management Review 32(4): 1096-1120.

. 2011. "A New Political Role of Business in a Globalized World: A Review and Research Agenda," Journal of Management Studies 48(4): 899-931.

Scherer, A. G., G. Palazzo, and D. Baumann. 2006. "Global Rules and Private Actors: Toward a New Role of the Transnational Corporation in Global Governance," Business Ethics Quarterly 16(4): 505-32.

Scherer, A. G., G. Palazzo, and D. Matten. 2009. "Introduction to the Special Issue: Globalization as a Challenge for Business Responsibilities," Business Ethics Quarterly 19(3): 327-47.

Schermerhorn, J. R. 1999. “Terms of Global Business Engagement in Ethically Challenging Environments: Applications to Burma,” Business Ethics Quarterly 9(3): 485-505.

Seelos, C., and J. Mair. 2005. "Social Entrepreneurship: Creating New Business Models to Serve the Poor," Business Horizons 48(3): 241-46.

Sen, A. 2004. "Elements of a Theory of Human Rights," Philosophy and Public Affairs 32(4): 315-56.

Sethi, S. P. 1987. The South African Quagmire: In Search of a Peaceful Path to Democratic Pluralism. Cambridge, Mass.: Ballinger Publishing Company.

Shue, H. 1988. "Mediating Duties," Ethics 98(4): 687-704.

1996. Basic Rights. Subsistence, Affluence, and U.S. Foreign Policy. Princeton, N.J.: Princeton University Press.

Simons, P. 2004. "Corporate Voluntarism and Human Rights: The Adequacy and Effectiveness of Voluntary Self-Regulation Regimes," Relations Industrielles/Industrial Relations 59(1): 101-41. 
Skogly, S. I. 2006. Beyond National Borders. States' Human Rights Obligations in International Cooperation. Antwerpen: Intersentia.

Smith, T. 1994. "The Power of Business for Human Rights," Business and Society Review 88: $36-38$.

Tripathi, S. 2005. "International Regulation of Multinational Corporations," Oxford Development Studies 33(1): 117-31.

Ulrich, P. 2008. Integrative Economic Ethics. Foundations of a Civilized Market Economy. Cambridge: Cambridge University Press.

United Nations. 2008a. Clarifying the Concepts of "Sphere of Influence" and "Complicity." Report of the Special Representative of the Secretary-General on the issue of human rights and transnational corporations and other business enterprises, John Ruggie. Human Rights Council, Eighth session, A/HRC/8/16, http://www.reports -and-materials.org/Ruggie-companion-report-15-May-2008.pdf.

United Nations. 2008b. "Human Rights Council, Eighth Session.” Protect Respect and Remedy: A Framework for Business and Human Rights. Report of the Special Representative of the Secretary-General on the issue of human rights and transnational corporations and other business enterprises, John Ruggie, A/HRC/8/5, http://daccessdds .un.org/doc/UNDOC/GEN/G08/128/61/PDF/G0812861.pdf?OpenElement.

Waddock, S., and N. Smith. 2000. "Relationships: The Real Challenge of Corporate Global Citizenship," Business and Society Review 105(1): 47-62.

Walsh, J. P. 2005. “Book Review Essay: Taking Stock of Stakeholder Management," Academy of Management Review 30(2): 426-52.

Weissbrodt, D. 2005. "Corporate Human Rights Responsibilities," Zeitschrift für Wirtschafts- und Unternehmensethik 6(3): 279-97.

Weissbrodt, D., and M. Kruger. 2003. "Norms on the Responsibilities of Transnational Corporations and other Business Enterprises with Regard to Human Rights," American Journal of International Law 97: 901-22.

Wells, C., and J. Elias. 2005. "Catching the Conscience of the King: Corporate Players on the International Stage," in Non-State Actors and Human Rights, ed. P. Alston, 141-75. Oxford: Oxford University Press.

Werhane, P. H. 1985. Persons, Rights, and Corporations. Englewood Cliffs, N. J.: Prentice Hall.

Wettstein, F. 2009a. "Beyond Voluntariness, Beyond CSR: Making a Case for Human Rights and Justice," Business and Society Review 114(1): 125-52.

2009b. Multinational Corporations and Global Justice. Human Rights Obligations of a Quasi-Governmental Institution. Stanford, Calif.: Stanford University Press.

2010. "The Duty to Protect: Corporate Complicity, Political Responsibility, and Human Rights Advocacy," Journal of Business Ethics 96(1): 33-47.

2012. "Silence as Complicity: Elements of a Corporate Duty to Speak Out against the Violation of Human Rights," Business Ethics Quarterly 22(1): 37-61. 
Wettstein, F., and S. Waddock. 2005. "Voluntary or Mandatory: That is (Not) the Question; Linking Corporate Citizenship to Human Rights Obligations for Business," Zeitschrift für Wirtschafts- und Unternehmensethik 6(3): 304-20.

Whelan, G., J. Moon, and M. Orlitzky. 2009. "Human Rights, Transnational Corporations, and Embedded Liberalism: What Chance Consensus," Journal of Business Ethics 87(2): 367-83.

White, J. 2004. “Globalization, Divestment and Human Rights in Burma," Journal of Corporate Citizenship 14: 47-65.

Williams, O. F. 1986. The Apartheid Crisis. How We Can Do Justice in a Land of Violence. San Francisco: Harper and Row Publishers.

2004. "The UN Global Compact: The Challenge and the Promise," Business Ethics Quarterly 14(4): 755-74.

Wood, S. 2012. "The Case for Leverage-Based Corporate Human Rights Responsibility," Business Ethics Quarterly 22(1): 63-98.

Young, I. M. 2003. "From Guilt to Solidarity: Sweatshops and Political Responsibility," Dissent 50(2): 39-44.

. 2004. "Responsibility and Global Labor Justice," Journal of Political Philosophy 12(4): 365-88. 